2015

\title{
Tilting at Stratification: Against a Divide in Legal Education
}

Rebecca Roiphe

New York Law School

Follow this and additional works at: http://digitalcommons.nyls.edu/fac_articles_chapters

Part of the Legal Education Commons, Legal Ethics and Professional Responsibility Commons, and the Legal Profession Commons

\section{Recommended Citation}

16 Nev. L.J. 227 (2015-2016)

This Article is brought to you for free and open access by the Faculty Scholarship at DigitalCommons@NYLS. It has been accepted for inclusion in Articles \& Chapters by an authorized administrator of DigitalCommons@NYLS. 


\title{
TILTING AT STRATIFICATION: AgAinst A Divide IN LEGAL EDUCATION
}

\author{
Rebecca Roiphe*
}

INTRODUCTION

Scholars and critics are debating the value of a law degree. They are fighting over how to predict the future of the profession, how to regulate the practice of law, and how best to train lawyers to meet the challenges of the future. ${ }^{1}$ Most recently, the American Bar Association Task Force on Legal Education weighed in with a strong critique of the standard model of legal education. Among other things, the Task Force urges schools to offer more training on concrete skills. ${ }^{2}$ Some critics have echoed this concern, explicitly calling for a divide between the top tier of law schools, which would train lawyers to serve global business clients by teaching the practice of law alongside broader study of jurisprudence, history, sociology, and political science, and a lower tier that would provide a shorter, cheaper education by focusing solely on practical skills. $^{3}$

The economics of the profession and legal education are changing so rapidly that the discussion might not even matter. The stratification of law schools

\footnotetext{
* Professor of Law, New York Law School. Ph.D University of Chicago. J.D. Harvard Law School. I am grateful to Elizabeth Chambliss and Doni Gewirtzman for their comments on earlier drafts of this article. I would also like to thank my colleague, William LaPiana, whose comprehensive and thoughtful study of legal education, made this project possible. My ideas evolved through the thought provoking discussions at the Ethics "Schmooze," sponsored by Fordham Law School and Touro Law Center. I would also like to thank New York Law School for its generous research support.

${ }^{1}$ See Paul Campos, The Crisis of the American Law School, 46 U. MICH. J.L. REFORM 177, 177-79 (2012); William D. Henderson \& Rachel M. Zahorsky, The Law School Bubble: How Long Will it Last if Law Grads Can't Pay Bills?, A.B.A. J. (January 1, 2012, 11:20 AM), http://www.abajournal.com/magazine/article/the_law_school_bubble_how_long_will_ it_last_if_law_grads_cant_pay_bills.

2 TAsk Force ON THE Future of Legal Educ, Am. Bar Ass'N., Report AND RECOMMENDATIONS 3 (2014), http://www.americanbar.org/content/dam/aba/administrative /professional_responsibility/report_and_recommendations_of_aba_task_force.authcheckdam .pdf. The $\mathrm{ABA}$ is also considering proposals to require 15 credits of experiential learning in law school. For a debate between Professor Stephen Ellmann and Brian Leiter on the value of the proposal, see Brian Leiter, Ellmann v. Leiter on the Proposed Clinical/Experiential Learning Requirement, BRIAN LEITER's L. SCH. REP. (Jan. 7, 2014), http://leiterlawschool. typepad.com/leiter/2014/01/ellmann-the-proposed-clinicalexperiential-learningrequirement.html

${ }^{3}$ See generally Brian Z. TAMANaHa, Failing LaW Schools (2012).
} 
into a top tier that educates its students in the nature of law, government, and democratic institutions and a lower tier that trains students to perform basic legal tasks may already be happening regardless of what anyone thinks is best. The drop in applications to law schools has forced many schools to re-examine the system of pricing and funding. ${ }^{4}$ The decline in applications and enrollment has similarly pushed these institutions, particularly those with lower ranked schools, to cut costs. ${ }^{5}$ It is not hard to imagine that one of the initial waves of cuts will be to faculty scholarship. Eventually, schools might give in to the fact that it is far cheaper to educate students without a full-time research faculty. ${ }^{6}$ Even if we cannot fully reverse this trend, it is critical for the bar, law schools, and other organizations to shape these changes in ways that will avoid or at least minimize the damage.

This article argues that the stratification of law school into two tiers, one that teaches theory and jurisprudence alongside practical skills and the other that focuses on the latter, would erode the positive professional identity and values that lawyers share. This divide threatens to undermine the education of the next generation of lawyers by failing to train the vast majority of lawyers, particularly those who serve the local government or individual clients, in a key aspect of every professional's practice: the negotiation of private interests with shared social norms. The proposal for stratification excludes, for these students, critical and important aspects of legal education, would leave these future lawyers unprepared to serve their clients, and deficient in the skills needed to serve the beneficial role in American democracy to which the profession has aspired and, at times, successfully achieved in the past. ${ }^{7}$

Brian Tamanaha, professor at Washington University Law School and the most well-known proponent of this sort of stratification, suggests we divide law schools into the elite tier whose graduates serve mostly global business clients

${ }^{4}$ In 2013 , the total number of law students enrolled fell by 11 percent. Jennifer Smith, U.S. Law School Enrollments Fall, WALL ST. J. (Dec. 17, 2013, 7:41 PM) http:/www.wsj.com /articles/SB10001424052702304858104579264730376317914. Scholars predicted another decline in applications of around 9 percent for the fall of 2014. See, Jerry Organ, Projections for Law School Enrollment for Fall 2014, L. PROFESSOR Blogs NeTwork (Mar. 18, 2014), http:/lawprofessors.typepad.com/legalwhiteboard/2014/03/projections-for-law-school-enroll ment-for-fall-2014.html. The Law School Admission Council has similarly predicted declines for 2015. See Three-Year Applicant Volume Graphs, LSAC, http:/www.lsac.org /1sacresources/data/three-year-volume, (last visited July 21, 2015).

5 Tania Karas, Facing Drops in Enrollment, Law Schools Cut Costs, N.Y. L.J. (Oct. 2, 2013), http:/www.newyorklawjournal.com/id=1202621710322.

${ }^{6}$ Paul Campos argues that the increase in the cost of law school derived in part from a greater number of faculty engaged in scholarship which reduced the teaching loads of most faculty members. See Campos, supra note 1, at 183-84. See also Matt Bodie, Funding Legal Scholarship: The Traditional Law School Model, PRAwFsBLAwg (Feb. 10, 2014), http://prawfsblawg.blogs.com/prawfsblawg/2014/02/funding-legal-scholarship-the-tradition al-law-school-model.html; Victor Fleischer, The Unseen Costs of Cutting Law School Faculty, DEALBOOK, N.Y. TIMEs (July 9, 2013, 3:46 PM), http://dealbook.nytimes.com/2013 $107 / 09 /$ the-unseen-costs-of-cutting-law-school-faculty/.

${ }^{7}$ Rebecca Roiphe, Redefining Professionalism, 26 U. FLA. J.L. \& PuB. POLICY 193 (2015). 
and a lower tier, preparing lawyers for the run of the mill dispute. This idea is not new. A strikingly similar proposal emerged in the early twentieth century, almost as soon as law schools themselves were established. ${ }^{8}$ This article draws on the history of the first debate over stratification to argue that the proposal to divide legal education into two tiers of law schools threatens professional identity and jeopardizes services to lower income clients. All lawyers engage in a complex negotiation between private interests and shared norms. To do this work well, practitioners of all sorts need practical skills, but they also need a theoretical understanding of the law. Successful lawyers need some version of history, jurisprudence, philosophy, economics, and political theory. Change in legal education is both necessary and inevitable. If we move toward specialized degrees, multiple sources of regulation, and varied degrees of education, I conclude that we ought to preserve a common background and ability among all practitioners to think critically about the nature of law and the relationship between the government and its citizens.

In 1920, the Carnegie Foundation commissioned one of its staff members, Alfred Z. Reed, to study legal education in the United States. ${ }^{9}$ The following year, Reed issued a comprehensive report, concluding that lawyers were operating under the pernicious myth of a unitary legal profession. ${ }^{10}$ Medicine had already divided along functional lines, by licensing nurses, physicians, dentists, and midwives differently. However, the law stubbornly clung to the idea that it constituted one learned profession. ${ }^{11}$ This failure to acknowledge the reality of professional stratification, according to Reed, had "evil" effects on the profession and its ability to serve the public. ${ }^{12}$

Throughout the twentieth century, critics have echoed Reed's concerns. Recently, the tone of this debate has grown more urgent. Scholars have achieved renown by reiterating Reed's now almost one-hundred-year-old denunciation of the system of legal education. Tamanaha and other critics, like Reed, advocate specialized degrees and segmentation of law schools into two tiers. ${ }^{13}$ Some recent critics emphasize the lack of practical training in contemporary law schools, while others focus on the debt load of students attending the lower ranked schools. ${ }^{14}$ Either way, the current trend favors segmentation both in terms of specialized degrees based on training and practice area and a divide based on law school rank. This side of the debate takes an egalitarian,

8 Alfred Zantzinger ReEd, Training For the Public Profession of the LaW 57 (1921).

${ }^{9}$ Id. at xiv-xvii.

${ }^{10} \mathrm{Id}$. at 57.

11 Id. at $\mathrm{xv}-\mathrm{xvi}$.

12 Id. at 57.

13 See generally Tamanaha, supra note 3.

14 Id. at 27; Brent E. Newton, Preaching What They Don't Practice: Why Law Faculties' Preoccupation with Impractical Scholarship and Devaluation of Practical Competencies Obstruct Reform in the Legal Academy, 62 S.C. L. REV 105, 106 (2010). 
folksy, and anti-intellectual tone. It charges the American Bar Association and others who resist the proposal with maintaining an elitist ideology.

The current proposal for two tiers of law school implicitly relies on a view of history that misrepresents and caricatures the early debate. The Bar, as Tamanaha's story goes, with its classist, racist, and self-interested desire to reinforce its own status and exclude immigrants and other outsiders from practice, imposed a unitary system of education and bar admission. ${ }^{15}$ This article unearths the politics of the early debate, arguing that the Bar's motivation was more benign than this oversimplified story represents. It draws on this more complex understanding of the historical context to argue that segmentation into two tiers of schools need not and ought not accompany increased specialization or differentiation among degrees. Specialization and differentiation are perhaps inevitable as the law grows more complex and practice more varied, but segmentation into two tiers of law school based on a divide between theory and practice and the economic status of clients is neither necessary nor desirable.

Reed is, perhaps, more well known for his early critique of the case method. ${ }^{16}$ His report criticized law schools for abandoning practical training in favor of an airy theoretical approach. ${ }^{17}$ Once again, echoing a current concern, Reed worried that students were graduating deficient in skills and lacking an ability to practice. ${ }^{18}$ Educated by the Socratic method, they were unprepared to work in the profession. ${ }^{19}$ His accusations must have seemed more pressing, as law schools were increasingly replacing apprenticeships as the primary training for new lawyers at the time he issued his report. ${ }^{20}$ But in fact, Reed was not as hostile to the case method as he seemed at first glance. He admitted, "lawyers who had been trained in this way outstripped, in practice, the product of other methods." ${ }^{21}$ What he really opposed was the assumption that this intellectual training was suited to the lower tier of practitioners, whom he viewed as less capable and intelligent as the elite.

Reed found the failure to recognize the reality of a fragmented legal profession tedious. ${ }^{22}$ He urged the Bar to acknowledge the fact that the profession was comprised of two bars, divided roughly along class lines. ${ }^{23}$ Reed suggested that law schools specialize, each one producing a different degree for different types of practitioners. ${ }^{24}$ Implicit in his proposal, was a related solution con-

15 See Tamanaha, supra note 3, at 21-27.

16 See REED, supra note 8, at 286.

17 Id. at 370 .

$18 \mathrm{Id}$.

${ }^{19} I d$.

20 See generally William P. LaPiana, Logic AND EXPERIENCE: THE ORIGIN OF MODERN AMERICAN LEGAL EdUCATION (1994); ROBERT STEVENS, LAW SCHOOL: LEGAL EDUCATION IN AMERICA FROM THE 1850S TO THE 1980s 174 (1983).

21 REED, supra note 8 , at 380 .

22 See id. at 405.

23 Id. at 415.

24 Id. at $414-15$ 
sistent with, but not necessary to, the first. Reed argued that law schools divide into two separate tiers: the full-time national schools, which would train lawyers in the complex theoretical nature of the law, and the part-time local schools, which would provide technical training to the vast majority of practitioners. ${ }^{25}$ In his model, the elite schools would persist in hiring full-time academics with an intellectual grasp of the complexities of the law, and the lower tier schools, which served mostly the lower middle class, immigrant, and minority students, would use practitioners to train the rank and file in the technical skills needed for law practice. ${ }^{26}$

Both Reed's proposal and the ABA's rabid response were, in part, fueled by the racism and xenophobia of Post-War America. Both sides were also peppered with insight and valuable warnings about the nature and fate of the profession. Both attempted to balance the need to educate lawyers to serve the public with the cost of legal education and access to the profession by newcomers. In revisiting this history, I expose the more sinister rhetoric of both sides of the debate and in doing so, highlight the real, stubborn problems that have persisted for almost a century. The history of this debate leads to two conclusions. First, the current proposal, most aggressively advocated by Brian Tamanaha, to revive Reed's proposal, relies on a caricature of the history of legal education. Second, we should move past oversimplifications and accusations that have plagued this perennial argument to think more creatively about how to stem the cost of legal education and broaden access to legal services. This must be achieved, however, without calcifying class divides or sacrificing both a rigorous legal education and the beneficial aspects of professionalism. ${ }^{27}$ If we alter the structure of legal education, we must do so without compromising the quality of legal services to poor and middle-income clients.

To make this argument, the first section of the paper details Reed's report and recommendation, teasing out both the valuable insight and the classist and racist motivations behind it. The second section explores the bar's reaction to Reed's denunciation of a unitary profession. Without refuting how elitist and cliquish the bar was, this section corrects a history that is unrealistic in its division of the past into heroes and villains. It rehabilitates the ABA (somewhat) by highlighting the valid concerns articulated by its members and unearths the condescending and equally elitist assumptions behind Reed's proposal. The third part of the article will demonstrate how the current critique of lower tier law schools relies on a mischaracterization of Reed's report and an oversimpli-

25 Id. at $411-12$

${ }^{26} I d$. at 412 .

${ }^{27}$ In previous articles, I have argued that professionalism has been unfairly reviled. While professionalism, like all broad concepts, has been used in the past to support self-interested and elitist ends, it has also served as an important reminder of the often noble role lawyers have played in American democracy. See Roiphe, supra note 7; Rebecca Roiphe, A History of Professionalism: Julius Henry Cohen and the Profession as a Route to Citizenship, 40 ForDHAM URB. L.J. 33, 34 (2012) 
fication of the bar's response. This part will show how the current proposal for two tiers of law school necessarily recycles the same classist, elitist assumptions in Reed's report. Finally, the article will conclude by highlighting the valuable concerns on both sides of the historical debate and discarding the selfinterested and retrograde biases. Clarifying the history of legal education helps direct and shape educational reform and this section will suggest some directions for future proposals which would address the serious concerns without replicating the elitist and racist assumptions that pervaded both sides of the historical dialogue.

\section{THE REED REPORT}

\section{A. Background: Legal Education from 1878-1921}

In 1879, the American Bar Association Committee on Legal Education issued a report recommending a three-year course of study in a law school equipped with a full-time faculty as a qualification for admission to the bar. ${ }^{28}$ After requesting the Committee to follow up on its recommendations, the ABA adopted resolutions urging states to ensure a proper three-year course of study and insisting that this ought to count as the equivalent of the same time spent as an apprentice in a law office. ${ }^{29} \mathrm{~A}$ decade later, in 1890 , the Committee on Legal Education once again issued a report, this time proposing a minimum study period of two years, and recommending three years for older states. ${ }^{30}$ The report went on to encourage schools to establish endowed chairs, maintain a library, and provide graduate courses. ${ }^{31}$ Throughout the following decades, the ABA continued to explore topics ranging from the importance of legal education to the public, how the law ought to be taught, the best sorts of examinations to evaluate students, the particulars of a good law school curriculum, and how best to teach young lawyers

The ABA claimed that the decline in standards of legal education came from market pressures. ${ }^{32}$ The schools were competing for students. They were eager for anyone to matriculate. As a result, the requirements and standards plummeted..$^{33}$ The public would suffer from unqualified lawyers who had been poorly trained. The purpose of the bar and the profession as a whole, according to the ABA, was to withstand market pressure to ensure that lawyers for clients of all means were capable and ethical. ${ }^{34}$

\footnotetext{
${ }^{28}$ Proceedings of the Fourth Annual Meeting of the American Bar Association, 4 ANN. REP. A.B.A 27,28 (1881).

${ }^{29}$ Id.

${ }^{30}$ Report of the Committee on Legal Education, 14 ANN. REP. A.B.A. 301, 349 (1891).

31 Id. at $349-50$

${ }^{32}$ Report of the Committee on Legal Education and Admissions to the Bar, 2 ANN. REP. A.B.A. 209, 216-18 (1879)

${ }^{33}$ See id. at 217

34 See id. at 209-10
} 
Legal education and requirements for admission to the bar varied radically when the bar was established. ${ }^{35} \mathrm{By}$ the turn of the twentieth century, the ABA was focused on developing standard rules for admission to the bar and standards to be applied to the law schools themselves. ${ }^{36}$ In 1906, the Section on Legal Education and Admission to the Bar's Committee drafted rules governing admission. ${ }^{37}$ The rules were debated, redrafted, circulated, and re-circulated among ABA members, judges, and law school deans. ${ }^{38}$ The final comprehensive and detailed report was issued in $1918 .{ }^{39}$ Among other things, it recommended that all candidates pass an examination administered by a board appointed by the state's highest court to gain admission to the bar. ${ }^{40}$ The report also insisted that lawyers pass a test of moral character. The most controversial recommendation, requiring three years full-time study (or four years of parttime study) in an approved law school, failed to pass. ${ }^{41}$

Questions about standards for law schools plagued reformers and policymakers at the time. They debated whether or not to require a college education before law school and if so, how many years and what sort ought to be required.$^{42}$ Lawyers worried about entry requirements. Should states require law office practice or law school as a prerequisite to sit for the bar? Should graduates of law schools have to pass the bar examination or should the school's own tests suffice $?^{43}$ In 1917, the Committee on Legal Education and Admission to the Bar proposed, and the ABA ultimately approved, a Council of Legal Education which would monitor and inspect the law schools, and suggest reforms to improve the standards of legal education. ${ }^{44}$ In 1920, prominent New York attorney and American statesman, Elihu Root, was elected chairman of the Section on Legal Education. ${ }^{45}$

35 See Proceedings of the American Bar Association 1 ANN. REP. A.B.A. 21, 26 (1878).

${ }^{36} I d$.

37 Report of Committee on Legal Education and Admissions to the Bar, 29 ANN. REP. A.B.A. 487, 495-96 (1906); See, e.g., Council of Legal Education, 41 ANN. REP. A.B.A. 71, 73-75 (1918); Report of the Council on Legal Education and of the Committee on Legal Education and Admissions to the Bar, 4 A.B.A. J. 413, 422-23 (1918).

38 See Council of Legal Education, supra note 37, at 73-75.

39 See Report of the Council on Legal Education and of the Committee on Legal Education and Admissions to the Bar, supra note 37 at 422-23.

40 Council of Legal Education, supra note 37, at 73-75.

${ }^{41}$ Id. at 75.

42 See LAPIANA, supra note 20 , at 132-47.

43 See id.

44 Report of the Committee on Legal Education and Admissions to the Bar, 40 ANN. REP. A.B.A. 447, 464-66 (1917). There was a similar organization in England called the Council on Legal Education, appointed by the Inns of Court. $I d$. at 465-66. The members of the Committee on Legal Education and Admission to the Bar were also aware that the American Medical Association had introduced a similar Council of Medical Education in 1904 to improve medical education in America. Id. at 466.

45 Proceedings of the Section of Legal Education and Admissions to the Bar, 43 ANN. REP. A.B.A. $465,465(1920)$. 
By the time Reed issued his report in 1921, law schools had multiplied, and more aspiring lawyers were choosing that path to the profession. ${ }^{46}$ The ABA and the American Association of Law Schools (AALS) had both publicly acknowledged that these institutions were preferable to apprenticeship. To this end, in the early decades of the twentieth century, the bar passed resolutions favoring educational requirements for bar admission. ${ }^{47}$ As the trend toward legal education gained momentum, however, there was little consensus or national uniformity in legal education. ${ }^{48}$

The debates over these early reforms unsurprisingly echoed and recast the broader social issues of the time. How much, if at all, should the profession ensure access by the poor? What should be done about the increasing numbers of immigrants in the country's urban centers? How should the profession react to Jews, blacks, and women, an increasing number of whom were demanding access to wealth and power? In 1916, one law professor and member of the AALS insisted: "we don't have to sit up nights to find ways for the poor boy to come to the Bar." "Edward T. Lee, the Dean of John Marshall Law School responded angrily, "don't slam the door in the face of brains." ${ }^{50}$ While overt racism and elitism sometimes peppered the debates, far more frequently, the prejudice and self-interest was masked by at least a seeming dedication to preserving the status of the profession while providing access to a new group of immigrants and minorities through a meritocracy.

When Reed published his report in 1921, the debate over legal education both reflected and shaped questions of race, class, and ethnicity. ${ }^{51}$ Social status and economic opportunism fueled all sides of the debate. Lawyers and policymakers on both sides of the divide were, at the same time, genuinely concerned about the public interest. ${ }^{52}$ Many believed in the critical and transformative role of lawyers in a democratic society ${ }^{53}$ In a world characterized by political corruption, some hoped that lawyers with no direct ties to political machines were necessary to police the justice system. Perhaps professionalism could fill in where institutions of finance and government had failed.$^{54}$ It would be simple to draw conclusions from a historical debate so similar to contemporary concerns if the good motivations lay one side of the argument and the self-interested and parochial ones lay on the other. But these issues, the good and the bad, jumbled together and motivated those on both sides of the debate.

46 See STEVENS, supra note, 20 at 73, 112-15; see also LAPIANA, supra note 20 , at 132-47.

47 STEVENS, supra note 20, at 96-97.

48 See generally LAPIANA, supra note 20.

49 STEVENS, supra note 20 , at 97.

${ }^{50} I d$. at 107 n.40 (quoting EDWARD T. LEE, THE STUDY OF LAW AND PROPER PREPARATION 5-6(1935)).

51 See LAPIANA, supra note 20 , at 86.

52 See STEVEN, supra note 20, at 101.

53 See id. at 101, 113.

54 See id. at 101. 
Reed was a pragmatist. He called on the bar to recognize the reality, as he saw it. There were two bars - the elite and the others. There were the Wall Street attorneys and the lawyers who solved everyday problems for individuals. Reed was accurate in his assessment of the growing divide among practitioners, though he may have exaggerated how distinct the two levels of practice were, when in fact there was a continuum as there is today. ${ }^{55}$ The other side was quick to point out that formalizing the distinction between the different classes of lawyers would calcify the categories and freeze the reality into a kind of professional caste system.

Reed explained that the law schools, which existed at the time, reflected these two classes of professionals ${ }^{56}$ On the one hand, the elite schools produced the leaders of government and business, and the part-time schools trained everyone else. ${ }^{57}$ The elite schools took the time to refine the already educated young men, to perform the most important tasks of a governing class. ${ }^{58}$ The night schools, on the other, satisfied the democratic impulse to ensure that the ranks of the profession remain open to all. ${ }^{59}$ Reed explained:

The full-time law school and the part-time law school proceed, accordingly, from different premises. The one seeks to serve the community by turning out well-educated lawyers. In pursuit of this aim, it must turn away those who cannot give to its work the requisite time. The other accepts the overflow and gives them all it can during the time at its disposal. It serves the purpose of keeping the privilege of practicing law from falling too exclusively into the hands of those who can afford the first type of education. ${ }^{60}$

While it is true that Reed wanted to ensure that the poor, children of immigrants, and other newcomers had access to the bar, he was also quite clear that the credentials mattered and he intended to make the distinction in both class and educational background clear at all levels of practice:

This differentiation of the schools into two types, each emphasizing one of the two fundamental characteristics of a bar admission system that are demanded by an efficiently governed democratic state, has much to commend it in its promise of future development. If law school graduates enjoyed different privileges in the practice of law, corresponding to the differences in educational effort between full-time and part-time work, the two types instead of rivaling would supplement one another. ${ }^{61}$

55 See generally Robert W. Gordon, "The Ideal and the Actual in the Law": Fantasies and Practices of New York City Lawyers, 1870-1910, in THE NEw High PrIESTS: LAWYERS IN POST-CiviL W AR AMERICA (Gerard Gawalt ed., 1984).

56 See generally REED, supra note 8, at 403-20.

57 See generally id.

58 See generally id.

59 See generally id.

${ }^{60}$ REED, supra note 8 , at $56-57$.

61 Id. at 57. 
In his proposal, each of the two tiers of school would have its own set of entry requirements and its own examinations. ${ }^{62}$ While Reed expressed commitment to access for all and democratic principles, he was perhaps more concerned with the fact that the part-time schools were dragging down the standards and reputations of the elite law schools ${ }^{63}$ He explained, full-time schools "are so fearful of losing students to institutions which-they are confident-are debauching the bar, that they hesitate to raise their own entrance requirements to the level that they really believe in. "*4t While Reed used the language of inclusion and access for all, his concern for the upwardly mobile immigrant was conveniently coupled with, and perhaps even dwarfed by, a desire to preserve the reputation and status of the elite.

At times, Reed seemed to draw the relevant distinction between full-time and part-time schools. But, in fact, he advocated most aggressively for a distinction between the elite schools and the "practitioner" schools, which included more than just the night schools. In discussing the different types of law schools and how they ought to educate their students, Reed wrote:

The scholarly law school dean properly seeks to build up a "nursery for judges" that will make American law what American law ought to be. The practitioner bar examiner, with his satellite schools, properly seeks to prepare students for the immediate practice of the law as it is. The night school authorities, finally, see most clearly that the interests not only of the individual but of the community demand that participation in the making and administration of the law shall be kept accessible to Lincoln's plain people. ${ }^{65}$

This passage reveals some of the assumptions behind Reed's proposal. First, Reed divided schools into those that trained judges and those that trained lawyers. ${ }^{66}$ In making this distinction, he took for granted that judges make the law, while lawyers do not. ${ }^{67}$ This assumption no longer accords with contemporary jurisprudence. ${ }^{68}$ It is a rather uncontroversial proposition that in a common law system like our own, lawyers, as well as judges, participate in the evolution of the law.

The second distinction Reed made is one based on class. ${ }^{69}$ By including night schools in this passage, Reed made it seem as if these part-time schools were doing something, which would justify different treatment. He failed to explain how the part-time schools differed in mission from the schools training the "practitioner." ${ }^{\prime 70}$ Nor did he explain how the work of the lawyers who grad-

${ }^{62}$ See id. at $\mathbf{5 7 - 5 8}$.

63 See id.

$64 I d$. at 58 .

65 Id. at 418 .

66 See id.

67 See id.

68 See generally W. BRADLEY WENDEL, LAWYERS AND FIDELITY TO LAW 49-86 (2010).

69 See generally REED, supra note 8, at 403-20.

70 See generally id. 
uated from the part-time schools differed significantly from those who graduated from the "practitioner bar examiner" school. ${ }^{71}$

Reed argued that the case method was a dangerous pedagogy for the less capable faculties in the part-time schools. ${ }^{72} \mathrm{He}$ explained, "[I]n the hands of a genuine scholar, skilled in the Socratic method, the case method is indubitably the best, in the hands of a mediocre man it is the very worst of all possible modes of instruction." ${ }^{73}$ Reed imagined a sharp divide not only in the capacity of the students, but also in the intelligence of the faculty ${ }^{74}$ While Reed's proposal seemed radical at the time, it was fueled by many of the same biases and prejudices of his opponents.

Reed did not hide his affection for the British system. He wrote,

$[\mathrm{T}]$ here has been at all times an element in the profession that has carried on the old traditions of the English bar. Originally composed for the most part of college graduates who studied in the best law offices, this element-although still very hazily defined - now tends to be composed of college graduates who have studied in the best law schools. ${ }^{75}$

He did acknowledge - albeit with a tone of resignation - that the uniquely American sensibility dictated greater access to the bar for the poor. ${ }^{76}$ But on a closer read, it is clear that in his proposal, only the lower rank of lawyer would be within reach of the outsider. ${ }^{77} \mathrm{He}$ accepted the permanent presence of "Lincoln's plain people," a lower tier of lawyer practitioners, but his proposal carefully relegated them to a very different sort of practice deserving a radically different sort of education and reputation. ${ }^{78}$ By creating a separate educational system, Reed hoped to create two castes of lawyers.

Reed, like several contemporary scholars, attributed the failure of the profession, in part, to its diffuse and incompatible elements. ${ }^{79}$ The bar had become too diverse; it had lost its social cohesion. ${ }^{80}$ The solution, according to Reed, was not to limit access but rather to recreate the fraternity in the elite bar, or ra-

71 See generally id.

${ }^{72} I d$. at 382.

${ }^{73} I d$.

74 See generally id.

75 See id. at 228 .

76 See id. at 398 .

77 See generally id. at $403-420$.

78 See generally id.

${ }^{79}$ See generally id.

80 Anthony Kronman developed the theory that the bar's decline was due in large part to its increasingly diverse membership. See generally ANTHONY T. KRONMAN, THE LOST LAWYER: FAILING IDEALS OF THE LEGAL PROFESSION (1993). More recently, Daniel Markovits has offered a similar argument in his book. See generally DANIEL MARKOVITS, A MODERN LEGAL ETHICS: ADVERSARY ADVOCACY IN A DEMOCRATIC AGE (2008). Markovits argues that, while it is theoretically possible for lawyers to live with integrity, they cannot do so in the modern age because the bar has lost its insularity. See generally id. at 213-49. 
ther, to acknowledge and celebrate the exclusivity that already existed. ${ }^{81} \mathrm{He}$ explained:

[A] bar that includes elements so diverse is a unitary profession only in theory. In actual practice its members cannot work together in a professional spirit. Differences in training and in social standing are recognized and we have actually a differentiated profession. Membership in selective bar associations produces an organic line of division, that is already to a considerable extent determined by considerations of this sort. The explicit recognition of educational standards as the basis of admission into these associations would constitute an important step toward the rational organization of the profession. ${ }^{82}$

Diversity in the profession troubled Reed ${ }^{83}$ In his mind (and this he shared with the opponents of his report) the new immigrant lawyers, with their different sensibility and style, dragged the entire profession down. ${ }^{84}$

Reed insisted that the only hope for a professional, ethical bar was to recognize and formalize the distinction that already existed:

Out of the wreckage of attorneys admitted to the bar, under the liberal admission rules prevailing in all the states, something resembling a genuine legal profession, based upon the selective principle, has indeed emerged. But it is a profession so disunited within itself as seriously to impair its capacity even to formulate-let alone to realize - professional ideals. $^{85}$

Reed appreciated the special qualities of the Anglo-Saxon race but insisted that the bar had to mask its elitism under the guise of educational standards rather than pure racism:

That blend of qualities which enter into the Anglo-Saxon concept of a 'gentleman' is a very precious heritage for an individual to possess; but anything that looks like a claim on the part of the well-bred to constitute a separate interest in the state provokes violent opposition from a still sensitive democracy. ${ }^{86}$

Thus, in order to maintain its exclusivity, its social cohesion, Reed believed the profession had to be separated into the "true professional" and the "practical craftsman." Local and state bar associations would have to reinforce the divide ${ }^{87}$ In other words, Reed explained, to maintain the dignity of the bar in the modern world, discrimination based on ethnicity, race, and gender would not be eradicated but rather masked as something else.

In Reed's proposal, bar associations would base admission on educational background. ${ }^{88}$ This would reinforce the divide among lawyers and protect the "inner bar" from being dragged down by the mere "craftsmen." ${ }^{89}$ Reed hoped

81 See REED, supra note 8 , at 64.

${ }^{82} \mathrm{Id}$.

83 See id.

84 See id. at 403-20.

$85 \mathrm{Id}$. at 215.

${ }^{86} \mathrm{Id}$. at 228

87 See id. at 228-29.

88 Id. at 229.

89 See id. 
to preserve the insularity of the bar by acknowledging and formalizing the two tiers of lawyers, each with its educational institutions, types of clients, bar organizations, and ethnic and socio-economic caste. At times, Reed suggested that the two sets of lawyers would be divided along functional lines, but ultimately he admitted that this would be impossible: "It is not even certain that a rigorous functional division of the bar will ever develop. The dividing line between the different types of lawyers may be determined by the economic status of the client rather than by the nature of the professional service rendered." 90 The divide, which he argued was necessitated by the different work lawyers did - the different functions they served - was defined instead by the wealth of the clients that they represented. ${ }^{91}$ Reed never explained why different educational standards were suited to different classes of clients. He never explained, for instance, why corporations needed lawyers with a complex theoretical understanding of the law but criminal defendants did not. Reed's proposal was, however, inextricably tied to this problematic assumption.

While at times he implied otherwise, Reed was convinced that lawyers were a critical piece in the democratic system. Not only government officials and judges, but also those in private practice were responsible for making the law. ${ }^{92}$ At times, Reed's proposal seems filled with a democratic spirit, insisting that given the importance of the profession's role, it would be wrong to keep common men from its ranks. He wrote,

Humanitarian and political considerations unite in leading us to approve of efforts to widen the circle of those who are able to study law. The organization of educational machinery especially designed to abolish economic handicaps intended to place the poor boy, so far as possible on an equal footing with the rich-constitutes one of America's fundamental ideals. ${ }^{93}$

He went on to explain that this was especially important for the training of lawyers: "It is particularly important that opportunity to exercise an essentially governmental function should be open to the mass of our citizens. " these passages out of context, one could easily mistake Reed for an egalitarian, ahead of his time.

But Reed insisted with at least as much certainty that the job of lawmaking ought to be siphoned off and monopolized by what he labeled the "inner bar," comprised of the white Anglo-Saxon gentlemen, as he sometimes referred to them: "It remains for a selected minority to render the public service, in the improvement of our law, that can be accomplished only by those whose training has been both broad and thorough. ${ }^{, 95}$

\footnotetext{
Id. at 419

91 Id.

${ }^{92} I d$. at 237

93 Id. at 398 .

94 Id.

95 Id. at 238 .
} 
While he had a condescending respect for what he would have categorized as the rank-and-file lawyer, Reed's proposal relegated those lawyers to a permanent lower tier. He concluded, "There is an abundant demand in the community for lawyers who are well informed and expert, but not necessarily profound; men whose knowledge is derived at second hand, but is none the less adequate for the purpose in view. ${ }^{96}$ In other words, because their clients were simple, the legal problems too must be simple, and those with inferior training or capacity would be able to handle them.

\section{THE BAR's RESPONSE}

The American Bar Association Section on Legal Education and Admission to the Bar received an early draft of Reed's report. ${ }^{97}$ In 1920 , it formed its own committee to respond and devise its own recommendations for legal education. ${ }^{98}$ Chaired by the prominent lawyer and leader in the bar, Elihu Root, the committee did not mask its horror in its opposition to the Reed Report. ${ }^{99}$ Insisting on the unitary nature of the legal profession, Root disagreed with Reed's premise that different forms of practice required inherently different preparation. ${ }^{100}$ The Root report concluded that recognizing different types of law schools would necessarily involve tolerating lower educational standards. ${ }^{101}$ In order to maintain the quality of legal education and the values and skill of the practicing bar, Root insisted law schools had to be uniform. ${ }^{102}$

By 1920, it is unsurprising that both Reed and the ABA accepted the reality of immigrants and ethnic minorities joining the profession. ${ }^{103}$ It is also unsurprising that given the climate in the early 1920 s, both Reed's proposal and the $A B A$ 's response reflected the deeply held nativism and xenophobia of post-war America. But Reed and the ABA responded to this fear differently. Reed hoped to relegate the less desirable newcomers to a separate class, to maintain the dignity and cohesion of the profession by branding this group serving a lower class of clients as a different type of lawyer. ${ }^{104}$ He hoped to create (or acknowledge) and celebrate a permanent underclass of common lawyers.

The Bar resisted Reed's proposal but not, for the most part, out of any greater affection for immigrant and minority lawyers. It hoped that by controlling admission, it could maintain the elite nature of the bar. Expensive and

96 Id. at 384 .

97 Report of the Special Committee to the Section of Legal Education and Admissions to the Bar of the American Bar Association, 44 ANN. REP. A.B.A. 679, 679-88 (1921) [hereinafter "Root Report"].

${ }^{98} I d$.

99 See generally id.

${ }^{100} I d$. at 681.

101 Id. at 679-87.

102 Id. at 681-82.

103 REED, supra note 8, at 62.

104 See supra Part I. 
time-consuming educational criteria would limit the type and extent of the newcomers. Many members of the American Bar Association hoped to manage the number of lawyers entering the lower tiers of the profession by maintaining strict educational requirements, which would make it difficult, if not impossible, for many to afford the luxury of law training. On the other hand, many bar members hoped that the carefully crafted education would also force the immigrant and minority lawyers, who did manage to make it through, to fit the mold created and policed by the elite lawyers. ${ }^{105}$ They hoped professional training would shape select worthy immigrants into proper lawyers and citizens. ${ }^{106}$

As historians have argued, the Progressive Era was a time of optimism, particularly a faith in human ability to transform and evolve. ${ }^{107}$ This sentiment, for instance, pervaded middle-class charity work, as many reformers believed that they could convert immigrants and minorities to what they believed was the superior and more civilized ways of the Anglo-Saxon race. ${ }^{108}$ The Progressive faith and optimism about the capacity for human transformation made its way into the ABA's response to Reed's proposal for segmented legal education. Of course the proposal was driven on some level by racism and prejudice but it was also mixed with a more open, if patronizing, attitude. Many proponents of Root's report believed that outsiders could be converted to the more sophisticated ways of the established professionals. While this idea of the professional melting pot was suffused with a sense of cultural superiority, it also provided a narrative of the self-made man made possible by an open educational system. If American educational standards were strict and uniform, worthy immigrants and their children might eventually join the ranks of the elite. Once the worthy few made their way through the rigorous requirements, they would have the same claim on power as anyone else. As naïve and condescending as this conviction may sound to us today, it did create a bar committed, albeit in a meager way, to the potential for outsiders to make their way in. Part of the Bar's response to Reed was fueled by an elitist desire to keep insiders out, but at least some members were also motivated by a faith in Americanization and assimilation that would allow truly gifted poor, immigrants, and minorities to succeed. ${ }^{109}$

In 1922, in response to Reed's report, the $\mathrm{ABA}$ resolved to encourage states to require two years of college and three years of law school study for

\footnotetext{
105 Proceedings of Section of Legal Education, 44 ANN. REP. A.B.A. $656,675-76$ (1921).

106 Id.

107 See Daniel T. Rodgers, In Search of Progressivism, 10 REV. AM. HIST. 113, 114 (1982).

108 See, e.g., id.; Thomas L. HAskell, The EMERgEnCE of Professional SoCial SCIENCE 234-56 (1977); Richard HofstadTER, SOCIAL DARWINISM IN AMERICAN THOUGHT 172 (Rev. ed. 1955); STEPHEN SKOWRONEK, BuILding A NeW AMERICAN STATE: ThE ExPansion of National AdMINISTRATIVE CAPACITIES: 1877-1920 (1982); Charles Taylor, SOURCES OF THE SELF: THE MAKING OF THE MODERN IDENTITY 393-418 (1989).

109 See e.g., Proceedings of Section of Legal Education, supra note 105, at 675-76.
} 
entry to the bar. ${ }^{110}$ The resolution would not have barred part-time schools, but such programs would have had to offer four years of training to make up for the time. In defense of this requirement, Root insisted that many lawyers are coming from foreign countries and he argued:

These young men to whom I have referred come here, and they are coming to our Bar by the hundreds, with continental ideas born in them. No cramming for an examination will get them out. They are not to be learned or dis-learned out of a book. Those ideas can be modified or adapted to our ideas only by contact with life-contact with American life-taking in, in the processes of life, some conception of what the American thought and feeling and underlying basis of honesty and justice is. ${ }^{111}$

By mingling with "young American boys and girls in those colleges," these newcomers would learn "something of the spirit of young America in its aspiration and its ambition, seeking to fit itself for greater things." 112 Drawing on the language of social Darwinism, popular at the time, Root dismissed criticism that this requirement would keep poor young men out, noting the persistence and dedication of the "plain boys" who succeed in America. ${ }^{113}$

Chief Justice William Howard Taft, similarly defended the proposal on the ground that education provided access to the poor, including the worthy new immigrants and their children. ${ }^{114} \mathrm{He}$ articulated a version of the American Dream very much in vogue at the time. ${ }^{115}$ It was precisely the high standards of the profession, the prestige of the bar, which made it a route to success in America. To illustrate his point, he told the story of his father, the son of a Vermont farmer, who walked hundreds of miles to Yale College so that he could get an education, become a lawyer, and contribute to society. ${ }^{116}$ The exclusivity of the profession made it a tribute to merit and an avenue to success. ${ }^{117}$

Regardless of the motives of some ABA lawyers, there was no doubt that Reed's proposal would have allowed more of the nation's poor and immigrants to join the ranks of the profession. The President of Yale, James B. Angell, admitted as much when he explained that the ABA's proposal would limit the number of "boys of modest means" who would become lawyers, but he concluded, "I suspect it would mainly be the weaklings who would be deterred and the Bar can perhaps do without such." 118 Like Root, Angell drew on the lan-

110 Proceedings of the Special Conference on Legal Education, 45 ANN. REP. A.B.A. 482 , 482-83 (1922)

111 Id. at 493 .

$112 I d$. at 494. Others echoed this sense that college trained citizens by instilling not only knowledge but character. Id. at 516-19 (address of Silas Strawn).

113 Id. at 494.

114 See id. at 498.

115 See id.

$116 I d$. at 499.

117 See id. at $499-500$.

${ }^{118} \mathrm{Id}$. at $\mathbf{5 2 2}$. 
guage of Social Darwinism popular at the time. ${ }^{119}$ Angell's statement reflected a naïve faith in meritocracy and education. Despite the admission that a uniformly required legal education would limit access to the profession, Angell insisted that colleges and universities were committed to making sure that "the man of fine character and substantial ability" can obtain a college and professional education regardless of his "economic circumstance." 120

Like Reed, the ABA emphasized the public nature of the legal profession. ${ }^{121}$ In defending the ABA's proposal, Clarence Goodwin, a prominent member of the Bar, asserted that legal education must reflect the profession's belief in "equality before the law." 122 He explained that the profession could not keep that promise when it allows states to permit the poor to be represented by "ignorant, untrained, and incompetent men." 123 One New York lawyer argued that the two-year college requirement was necessary to preserve the bar as an "intellectual aristocracy." 124

Many of the members of the bar who opposed Root's proposal were from the Mid-West. ${ }^{125}$ One dissenting voice, a lawyer from Indiana, responded that two years of college is certainly helpful, but it ought not to be required. ${ }^{126}$ Echoing a populist strain common in the early 1920s in America, he commented,

$[I] t$ is the man of average ability who is the salt of American citizenship. The average teacher in our schools makes the greatest contribution in character building. The average farmer, and not exceptionally superior farmers, feed the world, and it is to the average lawyer, in point of character and ability, to whom the people can look with the greatest confidence for the enactment of wholesome laws and wise interpretation thereof. ${ }^{127}$

The religious imagery mixed in with the anti-intellectual celebration of common man was a familiar current in conservative populist ideology at the time. ${ }^{128}$ Reed's report itself seems to embrace and celebrate an authentic com-

119 Id. See generally, HOFSTADTER, supra note 108

120 Proceedings of the Special Conference on Legal Education, supra note 110, at 528-29.

121 Complete Report of the Proceedings of the Special Session on Legal Education of the Conference of Bar Association Delegates at Washington, D.C., February 23-24, 1922, 7 MASs. L.Q., July 1922, at 10-11.

$122 I d$. at 11 .

$123 \mathrm{Id}$

$124 \mathrm{Id}$. at 71

125 See generally Complete Report of the Proceedings of the Special Session on Legal Education of the Conference of Bar Association Delegates at Washington, D.C., February 23 24,1922 , supra note 121 .

126 Id. at $37-40$.

$127 \mathrm{Id}$.; see also id. at 68 ("I can go out in the mountain sections of the State of Tennessee and you won't find any law cases there except hog cases and ejectment cases, but I can find a lawyer there who can try an ejectment case according to Tennessee law, who can run off of his feet any of the distinguished lawyers we have heard speak here this morning, not even excepting the distinguished nestor of the American Bar.").

128 See generally e.g., ALAN BRINKLEY, VOICES OF PROTEST (1983); RICHARD HOFSTADTER, ANTI-INTELLECTUALISM IN AMERICAN LIFE (1962). 
mon lawyer who need not aspire to great depths of thought but nonetheless gives back to his community. ${ }^{129}$

Reed and Root were not the first to study legal education. Josef Redlich, an Austrian observer had studied and reported on law school education seven years earlier. ${ }^{130}$ Redlich's report was based on a fairly spotty study. He visited only six schools, all elite institutions. Based on his observations, he concluded that there were at least two markets for legal education. ${ }^{131}$ He noted that the American spirit prevented even the most elite institutions from resembling Oxford or Cambridge because farmer's sons mixed with the urban middle class. ${ }^{132}$ But he also observed that most schools in America, which he labeled proprietary schools, served the needs "of those social strata whose sons are not thinking of university education in either the American or the continental sense. They consider the legal profession as a trade, like any other, and regard legal education in the same light as commercial education in a commercial school." $" 133$

Central to the debate between Reed and Root was a deeper, more fundamental question about education. To maintain high standards, schools had to increase costs, which, in turn led institutions to raise tuition. ${ }^{134}$ The high cost of education invariably deterred those who were, for whatever reason, born without advantages. Left to its own devices, as Reed noticed, the market dragged the standards of all the schools down. ${ }^{135}$ How could the system maintain high standards and bring the cost of education down? Reed would have admitted that his report did not solve the problem. What it did was split the baby by maintaining high standards for the elite schools and reducing tuition for the rank and file school. Root's proposal, on the other hand, maintained high standards in education but put the burden for inclusion on the individuals who wanted access.

How odd to find ourselves almost a century later with the same problems facing legal education and the same proposals suggested. While the history of this debate does not provide a solution, it does shed light on the current problem.

\section{CONTEMPORARY DEBATE}

While law schools in the decades that followed Reed's report and Root's response integrated more clinical and practical training, the Bar has been victo-

\footnotetext{
129 See generally, REED, supra note 8 (referring to lower class of lawyers as "Lincoln's Plain men" and otherwise glorifying the simplicity of the lower class and immigrant lawyer).

${ }^{130}$ See generally JoSEF RedLICH, The COMmon LAw AND tHe CASE METHOD IN AMERICAN UNIVERSITY LAW SCHOOLS (1914).

131 See id. at 70 .

${ }^{132} I d$.

133 Id.

134 See REED, supra note 8, at 185.

135 See id.
} 
rious in defeating Reed's more radical proposals. Reed's critique and proposal are, however, being raised with new urgency. ${ }^{136}$ Many law schools, under pressure from potential students, the media, and employers, are changing the way they teach. ${ }^{137}$ They are abandoning the old system as best they can and instituting a new regime to respond to allegations that law school training is too $a b$ stract and theoretical. ${ }^{138}$ Reed's critique, however, was coupled as it is today, with an assumption that the elite schools should continue as before and only the lower tier schools training the lower echelon of the bar need respond.

Echoes of the ideological strains in the positions in the debate in the $1920 \mathrm{~s}$ remain. The conservative populist position that grew in influence in the $1920 \mathrm{~s}$ is alive again today. Once again, it makes its way into assumptions about legal education. Of course, we need more practical training in law schools. Of course, clinics and externships are invaluable parts of the curriculum. But if lower tier law schools dispense with the intellectual education of lawyers, the profession is joining the lawyer from Indiana in the celebration of mediocrity, at least for a certain class of lawyers. Collectively, we are embracing a view that the wealth and status of clients ought to determine the caliber of their lawyers.

A conservative ideological trend, like that of the 1920 s, is gaining in popularity once again today. At the same time, preaching advancement through hard work and study is not as popular as it once was. ${ }^{139}$ Perhaps, this is because this promise is no longer realistic, as it is much harder to succeed through professional advancement than it was several decades ago. ${ }^{140}$ Whatever the cause, it is

136 See generally, e.g., Task Force on the Future of Legal Education (ABA, Working Paper, Aug. 1, 2013), http://www americanbar.org/content/dam/aba/administrative/professional_res ponsibility/taskforcecomments/aba_task_force_working_paper_august_2013.authcheckdam .pdf (discussing criticism of legal education and recommendations for the future).

137 See Courtney G. Lee, Changing Gears to Meet the "New Normal" in Legal Education, 53 DUQUESNE L. REV. 39, 40-52 (2015).

${ }^{138}$ There have been several proposals on the state and federal level to require students to complete a certain number of credits of experiential training. Michele Pistone, CLEA Calls on ABA to Require 15 Credits of Experiential Learning, BEST PRAC. FOR LEGAL EDUC. (July 1, 2013), http://bestpracticeslegaled.albanylawblogs.org/2013/07/01/clea-calls-on-aba-to-re quire-15-credits-of-experiential-learning/; Karen Sloan, ABA Reconsiders Practical Skills Mandate For Law Schools, NAT'L L.J., Dec. 9, 2013, http:/www.nationallawjournal.com /id=1202631585383/ABA-Reconsiders-Practical-Skills-Mandate-for-Law-Schools?slreturn $=20151030202353$.

${ }^{139}$ See, e.g., Ta-Nehisi Coates, How the Obama Administration Talks to Black America, ATLANTIC (May 20, 2013), http:/www theatlantic.com/politics/archive/2013/05/how-theobama-administration-talks-to-black-america/276015 (arguing that Barack and Michelle Obama's call for young black people to pursue an education contributes to pathologizing black America).

140 See Donald L. Bartlett \& James B. Steele, The Betray al of THe American Dream 126 (2012) (arguing student loan debt creates negative "domino effect" on economy); Joseph E. Stiglitz, Opinion, Student Debt and the Crushing of the American Dream, N.Y. TIMEs: OPINIONATOR BLOG, (May 12, 2013 9:09 PM), http://opinionator.blogs.nytimes.com/2013 105/12/student-debt-and-the-crushing-of-the-american-dream/? $\mathrm{r}=0$ (arguing student loan 
worth thinking about the debate over legal education in the context of attitudes toward education, in general. In addressing the recent calls for innovation in legal education and transformation in the legal profession, the bar ought to pause before joining the popular denunciation of legal education, especially in the lower tier schools. Instead, it ought to take a thoughtful stand on the cost of legal education, the nature of that education, and the provision of legal services.

The Bar is resisting the tide of criticism with less uniformity and less success. In August 2013, motivated by increasing tuition, student debt, declining applications and the limited jobs for law graduates, the ABA Task Force on Legal Education issued a working paper with the results of its study and several recommendations. ${ }^{141}$ There are a few themes that run throughout the working paper. ${ }^{142}$ The task force seems largely convinced that the "standard model" of legal education with university-based education and full-time faculty members no longer makes sense. ${ }^{143}$ In addition, it concludes that we need more heterogeneity in legal education. ${ }^{144}$

While heterogeneity may be both inevitable and desirable, it could result in two possible outcomes. It could result in Reed and Tamanaha's vision of two tiers of schools with different missions: One to teach the complex nature of rules and interpretation to students who will serve wealthy clients and the other to provide technical training in legal practice to those who will work for people of more modest means. It could alternatively dissolve law schools entirely. The profession could disappear into so many specialties. Either way we lose a common identity among professionals.

The call for reform in legal education today is almost entirely focused on the interests of lawyers and aspiring lawyers. The call for more experiential learning, better job placement, and reduced tuition are all largely responding to the needs of law students and lawyers. ${ }^{145}$ While serving this constituency is one purpose of law schools, educators are also responsible for ensuring the integrity of the justice system and increasing access to justice for the poor. Tamanaha's proposal might answer some of the ways in which law school has disserved law students and lawyers, but it does not necessarily help, and may potentially hurt, the larger duty that legal educators have to the public.

debt and improper mortgage-backed securities trading hamper social and economic opportunity).

141 See generally Task Force on the Future of Legal Education, supra note 136.

${ }^{142} I d$.

143 See id. at 13

$144 I d$. at 2.

145 Elizabeth Chambliss has argued that the focus on lawyers and aspiring lawyers has eclipsed the equally important responsibility that the profession has to clients, the justice system, and the unmet legal needs of the poor and middle class. Elizabeth Chambliss, Law For All? The First Thing We Do, Let's Educate the Non-Lawyers, JoTwELL, (Apr. 29, 2013), $\mathrm{http} / /$ legalpro.jotwell.com/law-for-all-the-first-thing-we-do-lets-educate-the-non-lawyers $/$ ?utm_source $=$ feedburner\&utm $\_$medium $=$feed\&utm $\_$campaign $=$Feed $\% 3 \mathrm{~A}+$ Jotwell $+\% 28 \mathrm{Jot}$ well $\% 29 \& u t m \_$content $=$Google + Reader. 
Unsurprisingly, the century old solutions put forward by Reed and the ABA did not solve the underlying problem. The similar debate today shows stubborn the problem really is. ${ }^{146}$ Education is expensive. How do we ensure that those without resources have access to education without compromising the quality of the education and the services that the profession renders? How do we expand access to legal education while simultaneously responding to the needs of the public? These are difficult questions without easy answers. Certainly relying on defunct proposals from the past, which absorbed and reflected bias and elitism cannot provide the answer.

\section{REVISED History AND THE CURRENT CRITIQUE}

Brian Tamanaha is not the first to launch this current crusade to alter the nature of legal education and reduce the course of study in most schools to two years. ${ }^{147} \mathrm{He}$ is, at least arguably, the most popular and prominent proponent of the stratified approach to legal education now. ${ }^{148}$ His book, Failing Law Schools, featured prominently and inspired the storm of media attention in the past year or so on legal education. ${ }^{149}$

Tamanaha's argument relies on an oversimplified and largely outdated version of this historical debate. ${ }^{150}$ Citing few sources and relying mostly on an article Jerold Auerbach published in 1971, Tamanaha frames his critique by arguing that the $\mathrm{ABA}$ and the American Association of Law Schools together conspired to serve the interests of the elite bar and the emerging elite law schools. ${ }^{151}$ The ABA used the ideology of the case method to argue that lawyers would reform society through their mastery of the science of the law. As such, they had a duty to the public to exclude the "poorly educated, the illprepared, and the morally weak candidates." ${ }^{152}$ Auerbach concluded, and Ta-

146 See id.

147 See supra Part I.

148 See Charles Lane, Book Review: 'Failing Law Schools' by Brian Z. Tamanaha, WASH. PosT, Aug. 3, 2012, https:/www.washingtonpost.com/opinions/book-review-failing-lawschools-by-brian-z-tamanaha/2012/08/03/e7054c9c-c6df-11e1-916d-a4bc61efcad8_story hitml (book review).

${ }^{149}$ Paul Campos created a blog called "Inside the Law School Scam" and in his first post, he argued that law professors are "scamming their students." Paul Campos, Welcome to My Nightmare, INSIDE THE L. SCH. SCAM (Aug. 7, 2011), http://insidethelawschoolscam.blogspot .com. Major newspapers and magazines followed with sensational articles about legal education. See e.g., Steven J. Harper, Law School Is a Sham, SALON (Apr. 6, 2013, 9:00 AM), http:/Www.salon.com/2013/04/06/law_school_is_a_sham/; Gus Lubin, 'Going to Law School Was the Biggest Mistake of My Life', Bus. INSIDER (Jan. 24, 2013, 5:14 PM), http://www.businessinsider.com/law-school-was-huge-mistake-2013-1; Tucker Max, Why You Should Not Go to Law School, Huffington Post (Apr. 20, 2013, 5:12 AM), http://www.huffingtonpost.com/tucker-max/law-school_b_2713943.html.

150 See TAMANAHA, supra note 3 , at 20-28.

151 Id.

152 Jerold S. AuERbach, Unequal Justice: Lawyers and SOCIAL Change in Modern AMERICA 107 (1976) (quoting the president of the Caregie Foundation). 
manaha reports, that this was code for Jews, blacks, and immigrants. ${ }^{153}$ The ABA, which comprised a little over 9 percent of practicing attorneys in 1920 , was acting like a cartel. It used the rhetoric of professionalism-its supposed role in protecting the public-to justify limiting its competition and maintaining control over entry requirements. ${ }^{154}$

While this description of the history of the profession is not entirely wrong, it is incomplete. It provides only a partial truth and a partial explanation for the profession we have inherited. Motivations are complex and ideologies survive because they are vague and amorphous. Professionalism too is vague. It encompasses the self-serving elitist motivations that Auerbach identified and Tamanaha invokes. But it also embodies an aspiration that the profession must serve a role in promoting justice and protecting democracy.

\section{CONCLUSION}

It is hard to draw a moral from history, which is always messier than one would like it to be. The dispute between Reed and Root was not a fight between good and evil where evil won out. The history of the dispute should, however, steer us away from the easy answers. Neither of the two solutions proposed in the 1920s adequately addresses the problems of quality in legal education, access to the profession, the cost of legal education and services. Both suffer from a form of elitism and fear of the outsider making his or her way in.

With that in mind, the best way to approach the problem is to acknowledge that we need to ensure that those without resources can access professional education, but we need to make that education meaningful to ensure that the access is giving them something more than a means of making a living. If the law is, as both Reed and Root believed, an important component of the democratic government, then we have to train all lawyers in how to govern. To do that, any proposal for legal education will need to provide lawyers with an understanding of the theoretical framework in which they will operate. All lawyers need both practical training and a theoretical understanding of what the law is and the means of assessing what the law ought to be. The wealth and status of clients should not determine whether or not a lawyer has this necessary understanding and training.

The history of the debate over Reed's proposal for two tiers of legal education helps unearth the complexity of the problem. Good answers have eluded us not because the bad guys have stood in the way but because they are hard to devise. As we reimagine legal education, however, we ought to think about what skills are essential to law practice of all sorts and then we ought to think about how to expand the access to legal education. To avoid the elitism in both Reed and Root's proposals, we ought to avoid the idea that only the elite need to study theory and only the rank and file need to learn how to practice. All

153 Id.; TAMANAHA, supra note 3, at 20-28.

154 REED, supra note 8 , at 216 
lawyers need to be educated in both theory and practice. The challenge is how to provide the skill and intellectual training while expanding access to an education, which is valuable to both students and society as a whole. 
